Instructions for authors, subscriptions and further details:

\title{
Queering Catholic Fundamentalism: On Liking Theology in Masculinities Research
}

Kevin J. Burke ${ }^{1}$

1) University of Georgia, United States

Date of publication: June $21^{\text {st }}, 2015$

Edition period: June 2015-October 2015

To cite this article: Burke, K.J. (2015). Queering Catholic Fundamentalism: On Liking Theology in Masculinities Research. Masculinities and Social Change, 4(2), 144-162. doi: 10.17583/MCS.2015.1509

To link this article: http://dx.doi.org/10.17583/msc.2015.1509

\section{PLEASE SCROLL DOWN FOR ARTICLE}

The terms and conditions of use are related to the Open Journal System and to Creative Commons Attribution License (CC-BY). 


\title{
Queering Catholic Fundamentalism: On Liking Theology in Masculinities Research
}

Kevin J. Burke

University of Georgia, United States

\begin{abstract}
This article seeks to build on recent movement in the fields of religion and gender studies in order to analyze and critically reflect on "the relation, confrontation and intersection of gender and religion" (Korte, 2011, p. 2). Here the author works to investigate the possibility that emerges in new forms of analysis that marry theological interventions with masculinities studies as a way to newly attend to patriarchy and fundamentalism. Utilizing feminist Catholic theology, the work addresses unique and recent problems that have emerged in the Church in the face of a new era that appears both more progressive and that has engendered conservative backlash. Along the way the article addresses issues of gender and sexuality as they relate to the priesthood and Pope Francis' recent assertions linking gender theory to ideological colonization and even nuclear armaments.
\end{abstract}

Keywords: suicide behavior, homosexuality, homophobia, hegemonic masculinity 


\section{Haciendo Queer el Fundamentalismo Católico: El Gusto por la Teología en la Investigación sobre Masculinidades}

Kevin Burke

University of Notre Dame, United States

\section{Resumen}

Este artículo trata de aprovechar reciente movimiento en el campo de la religión y los estudios de género con el fin de analizar y reflexionar críticamente sobre " la relación, la confrontación y la intersección de género y la religión " (Korte, 2011, p. 2). Aquí el autor trabaja para investigar la posibilidad de que emerge en nuevas formas de análisis que se casan con las intervenciones teológicas con estudios de masculinidades como una forma de recién asistir al patriarcado y el fundamentalismo. Utilizando la teología católica feminista, la obra aborda los problemas únicos y recientes que han surgido en la Iglesia en la cara de una nueva era que aparece tanto más progresista y ha engendrado reacción conservadora. En el camino el artículo se ocupa de cuestiones de género y sexualidad en su relación con el sacerdocio y las afirmaciones recientes Francisco que vinculan la teoría de género a la colonización ideológica e incluso armamentos nucleares.

Palabras clave: teología feminista, catolicismo, masculinidades, cristianismo muscular 

"Western culture...made a persistent effort to transfer male anxieties onto women (and feminized men) and turned the female anatomy into the antithesis of the male body. Women are fluid; men are not. They are dirty; we are not" (Krondorfer, 2010, p. 63).

"Masculinity is built partly on the vigorous disavowal of female masculinity and partly on a simultaneous reconstruction of male masculinity in imitation of the female masculinity it claims to have rejected"

(Halberstam, 1998, p. 49).

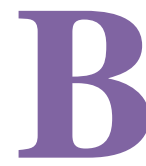

utler (2004), in a precursor to her more recent work on grievability and precariousness (e.g. 2010), suggests that the question of humanity in and through gender and queer (and really any, hopefully) theory ought to be "What constitutes the limit of what can be thought as true?" (2004, p. 156). This role of truth will become more important as we delve into religion and its hold (precarious itself or defensive, perhaps) on certain kinds of ontologies. But given that we will in this space discuss Catholicism narrowly, and religion more broadly, it's worth recalling the powerful and perhaps un/limited applications of certain interpretations of John 14:6: "I am the way, the truth, and the life." Still, one might ask in certain fields of academic study whether and if there can be truths found through tools and traditions not much leveraged or often dismissed for their supposed irrelevance if not irrationality. In this case I write very particularly about religion and its constitutive partner, theology. What might be gained, in other words, were scholars of gender and particularly masculinities, to leverage theological interventions and concepts within the field more consistently and robustly, particularly in response to the very failings of religion that have pushed queer folks, and researchers more broadly, away from churches over the century (millennia, perhaps)?

For now it's worth considering that saying "that gender is performative is not simply to insist on a right to produce a pleasurable and subversive spectacle but to allegorize the spectacular and consequential ways in which reality is both reproduced and contested" (Butler, 2004, p. 30). This work seeks to consider the limits of truth as read through the particular truths that 
are produced in a specific, and ongoing, moment in the Catholic Church. It does so utilizing critical feminist theological texts as a way to understand and challenge certain forms of differently emergent patriarchy in contemporary Catholic discourse and practice. Of course Catholicism is not the only major religion in the world perpetuating problematic gendered and sexual teachings behind the scrim of dogma; indeed other scholars have done good work thinking through fundamentalism and gender across various religious traditions (e.g. DeConick, 2011; Madigan, 2011). In this space, however, I emplace my engagement within the Catholic tradition because of my own expertise (see: Burke, 2011; 2012) and the desire to begin a conversation that scholars of masculinities elsewhere in the world might continue it in contextually specific ways.

Here I examine recent movements, read through the lenses of masculinities studies, queer theory and particularly feminist theology, in order to make sense of the kinds of realities around gender and masculinity that (might) become reproduced and contested. With this work I hope to "find the shape of a new story that starts to emerge when there is a rupture in impossibility" (Alison, 2003, p. xi) when we a) take religion seriously (Nord \& Haynes, 1998) in masculinities studies and b) look to resacralize the social sciences (Wexler, 2013) not to proselytize but to think about what to do when "we are caught up in the world of giving sacred meanings" where we are thus potentially "caught up in the world of reciprocal violence, of good and bad measured over against other people" (p. 9). The notion is - in a world where religion does much work in reinforcing reductive views of gender, and particularly masculinities, where some certain lives become impossible — that the tools of theology might best serve us in thinking of how to create the necessary ruptures in impossibility to move forward. One might, then, in this regard, turn to Johnson's (2007) Quest for the Living God which notes that, especially in a religious sense, "holding our truth as absolutely true does not mean we have to consider ourselves in possession of all the truth worth having. For God is greater than our heart"' (p. 177). In a similar vein, the social sciences broadly, and masculinities studies more narrowly might perhaps do well to let go of the sense that a truth that considers religion as only ever in need of rebuttal or as beyond rationality misses the possibility of: 
An entirely different map and sets of not-easily-accessed processes for the creation and distribution of power that would require us to think less in terms of conventional resources and institutions, and more toward the less visible, more interior and esoteric forms of power as demanding our theoretical attention. (Wexler, 2013, p. 67)

But what, then, does all of this have to do with the Catholic Church, as thought through masculinities studies in particular?

\section{The New Emangelization}

After his deposal from the Apostolic Signatura and demotion to the largely symbolic role of Patron of the Order of the Knights of Malta, American Cardinal Raymond Burke, a noted culture warrior, has taken the mantle of anti-reformer within the Roman Catholic Church, sniping at proposals from the current Pope Francis who has sought something of a détente (at least as reported widely) around issues related to gender and sexuality in the Church. ${ }^{1}$ Should the above be largely gibberish to you, please know that you aren't alone. One of the shortcomings of masculinities studies falls in the ways in which it fails, often, to engage with organized religion in more than cursory ways (e.g. Harris, 1995; McCormack, 2012). It's not vital that members of the research community track the ministrations of the Roman Curia (or any other administrative body related to a multinational religious organization like the Vatican), but it is the case that the field often misses out on the rich theological writings that might be drawn upon to rebut religious arguments aimed at reifying gender conformity through fundamentalist interpretations of dogma (see: Alison, 2001, 2003 for happy exceptions). That is: as the field expands and deepens, it makes sense to push its interdisciplinarity into new realms. In this case, theology and religious studies seem ripe for engagement. For, in the face of arguments referring to "God's plan"” it's worth using theology to point out that such pablum is “often a front for men's plans and a cover for inadequacy, ignorance, and evil" (Daly, 1972, p. 30).

Madigan (2011) notes that "since a central concern of fundamentalism is to restore what is claimed to be a hierarchical and divinely sanctioned patriarchal social order feminism [and its offshoots, like Masculinities Studies] above all is opposed as essentially inimical to fundamentalist 
objectives" (p. 48). This is, clearly, not merely a Catholic (nor Christian) problem. However, in this article I propose a revision of masculinities to include and engage, in particular, radical, queer, and feminist theology as a challenge to "Christology" that "has become androlatry and therefore idolatry" (p. 116). Which would mean both "taking such a term as 'homosexual' out of the context of negative judgments and allowing it to mean a deep and intimate relationship with a person of the same sex, with or without genital activity" (Daly, 1985, p. 126) while also closely examining "at the heart of patriarchy...the economic dependency of women and control of women's reproductive power" (Madigan, 2011, p. 99). One might, as here, engage women theologians writing of the Church, or particularly, find ruptures rooted in the marriage of masculinities studies and religion. Krondorfer (2010) does some of this work in proposing the critical engagement with the "confessiography" (p. 8) by which men in particular produce the (heavily mediated) self through writing and reading in the confessional mode (p. 9). Couched in an era (or eras) where "paradigms, authorities, or technologies lose their persuasive or coercive power" and "masculine identities become unstable...some men...confess their conflicted soul" (p. 234). This is not a work seeking to force the confessional on the field of Masculinities. Rather, what I aim is to comprehend movements in Catholic fundamentalism in recent years, using old tools in new ways to provide another route toward understanding and eventually, inherently, rebuttal.

There are hopeful movements related to this particular critique; the journal Religion and Gender ${ }^{2}$ is just one; the Journal of Men, Masculinities and Spirituality ${ }^{3}$ was another. What I propose here, however, is an engagement in masculinities studies that takes seriously theological arguments as a ready critique to the kind of complementarity and essentialization that is perhaps most studiously upheld in the teachings of Pope John Paul II and his Theology of the Body which, for Madigan (2011), "continued the papal tendency to idealize women, constantly highlighting the 'dignity' of women" while "never adequately address[ing] the contextual issues of women's social and economic disadvantage, including women's lack of voice and agency in the church" (p. 119). This served to reinforce teachings centered on gender (and sexual) complementarity and continues to reify a structured separation of women and men, masculinity 
and femininity that was inscribed, by the Pope in particular, as ontological as well as dogmatic. Its contemporary manifestations remain with us in particular in two new turns in conservative/fundamentalist circles of the Church (and other churches it should be said) fixing blame on women (and feminized and particularly gay men) for the downfall of the Catholic clergy - both morally in the ongoing sexual abuse crisis and in the crisis of falling vocations - and seeking to assert a renewed church through a version of the "'third wave' of Muscular Christianity" (Gelfer, 2013, p. 78). This latter shift has led in some Protestant denominations to the rise of socalled Mixed-Martial Arts style 'fight churches ${ }^{3}$ but it has manifest in Catholic circles in particular in the form of a new insularity wrought within the priesthood that asserts a "Man Crisis in the Catholic Church" brought on, at least in part by the insidious presence of women and girls on the altar. The threat to the male priesthood brought by girls in albs standing beside prelates cannot be underestimated in the eyes of the aforementioned Cardinal Burke for:

[the introduction of female alter servers] has contributed to a loss of priestly vocations. It requires a certain manly discipline to serve as an altar boy in the service at the side of [a] priest, and most priests have their first deep experiences of the liturgy as altar boys. If we are not training young men as altar boys, giving them an experience of serving God in the liturgy, we should not be surprised that vocations have fallen dramatically. ${ }^{6}$

The interview with the Cardinal comes from the New Emangelization Project which takes as its mission "drawing men to Jesus Christ and His Catholic Church" and mirrors Pope Benedict's call for a New Evangelization meant to "deepen [Catholic] faith" through an evangelization that goes forth into the world and 're-proposes' the Gospel. This concern regarding "female pollution" (Thorne, 1993, p. 83) is tied to Kristeva's notion of the abject, which "provokes fear and disgust because it exposes the border between self and other. This border is fragile. The abject threatens to dissolve the subject by dissolving the border" (Longhurst, 2001, p. 20). Particularly given the supposed ontological change that occurs to men in the Catholic faith who are ordained priests - in a faith where women are famously denied ordination — the need to maintain boundaries 
at or around the altar, especially in fundamentalist circles makes a certain kind of sense. Here we see the glimpse of a very real danger for patriarchy and hierarchy in the Church for if girls can serve at the altar just like their male counterparts, perhaps the gender divide between them that sorts boys neatly into the possible for the priesthood, might be fragile enough to allow women to perform the rites of the Eucharist and be directly tied to Transubstantiation. And close examination of Burke's statement renders it logically incoherent since of course girls have been allowed the role of altar servers for years; unless the good Cardinal is engaging the various manifestations of female masculinities in the world (he's not), one fears he has rendered his own statements wholly moot.

Performativity reveals the possible in this space whereby "the various acts of gender create the idea of gender, and without those acts, there would be no gender at all" (Butler, 2008, p. 190). In this sense, Burke's comments have a certain logic to them: polluted by the possibility that girls might actually be just as capable as boys in altar serving, that which is ontologically different about boys, that makes them, thus, able for the priesthood, starts to melt away. Of course blaming girls for the downfall of the priesthood is one approach; quite another might include "seek[ing] out forms of behavior which challenge exclusionary and dominative social practices, and not leave the values of compassion and solidarity at an ineffective level of abstraction" (Cahill, 1996, p. 129).

It makes sense, then, to think about the ways in which a "concentration on gender differences rather than gender relations" (Mac an Ghaill, 1994, p. 68) within a given religious tradition might produce a dogma of complementarity that must needs be guarded, fiercely and reductively. What is perhaps less well engaged, at least in the masculinities literature is an explicit linking between the ways in which "families are not closed universes but places where larger structures meet and interact" (Connell, 1982, p. 73) especially as regards the structuring practices of religion. Certainly Connell (2002) has written about "a refusal by men to be under the authority of women" (and feminized men) "in many religions, among them Catholic Christianity, mainstream Islam, and some sects of Buddhism" (p. 6). But how, we should ask, might theology (the undergirding structure holding up such refusals of authority) be made to speak differently, to perform new things, new genders, new sexualities, new 


\section{Kevin J. Burke - Liking Theology in Masculinities Research}

possible lives? That is: Masculinities may well be comfortable enough in thinking about religion, even challenging its claims, but what might be gained in addressing problematic notions about gender and sexuality with a resacralization that takes theology seriously on its own terms?

It would seem (and many have argued) that the election of Jorge Bergoglio as Pope Francis in 2013 might suggest more nuanced (progressive, even, given his off the cuff comment regarding gays: "who am I to judge?" $)$ approaches both to women and to the various developments in the study of gender construction over the last forty years. Certainly the very public rebuke of Burke, and his reduction to something of a guttersnipe in the formal structure of the Church, suggests movement in a new (if not a different) direction for the Church. What is missing, however, is an in-depth discussion of the current backlash against such seeming progress within the Church that has repercussions far beyond the roughly 1.2 billion Catholics in the world ${ }^{9}$ and the vast numbers of exCatholics ${ }^{10}$ raised in and inevitably informed by restrictive teachings of the Church regarding gender and sexuality. Going forward I draw from feminist religious studies and recent events within the Church to illustrate what an informed theological critique might look like, rooted in masculinities studies and in response in particular to a new kind of muscular Catholicism that offers an historical precedent for a historically contextual, and theologically limited "masculine-identified Christianity that promotes...masculine normativity" (Gelfer, 2013, p. 86).

\section{Muscular Christianity and a Gay Priesthood}

Kimmel (2012) tracks the various iterations of muscular Christianity over time noting that the first manifestation, at least in the American context "was imported from England through...novels... which fused a hardy physical manliness with ideals of Christian service" (p. 129). Within the movement in the late $19^{\text {th }}$ and early $20^{\text {th }}$ century, "prayer" became "'a manly duty"" (p. 130) in a "religion rippling with hard muscles, manly grit coupled with moral resolve" (p. 131). Late $20^{\text {th }}$ century versions of the movement became more closely tied to athletics and capitalism; these "masculinists insisted that the separation of the sexes was the only way to preserve what is different (and interesting) about either women or men" ( $p$. 
227). Kimmel circles back as well, tracing the development and flourishing of mid-century all-male clubs as "refuges" from the intrusion of women (and other others, certainly).

In Catholic circles, the all-male club for the laity (something like the Knights of Columbus or single-sexed schools) was always secondary to the ultimate all-male sanctuary of the priesthood. And while the calling of celibacy has been readily tied to the Greek valuation of male abstemiousness in the face of desire (Foucault, 1988), Catholic religious tradition has held it as also an unique cross to bear, and one that was viewed as preferential for men to even marriage (prior to Vatican II explicitly and one might argue even still, though tacitly). In the midst of that all-male club however has always run a quiet and robust gay priesthood. This is not to suggest 'gayness' such as it is somehow runs counter to the masculine, but it does tend to complicate more structural visions of Connell's (1995) original (though much modified and constructively nuanced in the intervening years) sense of 'Hegemonic masculinity' which "is not a fixed character type" but which is rather "the masculinity that occupies the hegemonic position in a given pattern of gender relations, a position always contestable" (p. 76). In this sense, then, it's useful to note Connell's assertion that "at any given time, one form of masculinity rather than others is culturally exalted" (p. 77). Pascoe (2007) makes the point differently noting that we are at our best in research in sexualities and masculinities in particular when we "think about sexuality as an organizing principle of social life" such that "it is not just the property of individuals" (p. 9). Here we find that generally speaking "male homosexuality is not pathologized but gay male effeminacy is. The lack of masculinity is the problem, not the sexual practice or orientation" (p. 59). Certainly Church teaching around the ontological failings of gay individuals complicates this assertion, but it is in particular the cauterizing of gay male activity marked as particularly notable because of its linkage with effeminacy that suggests a danger against which, it should be said, some in the Church have steeled themselves.

Within the Church - its hierarchy, and more conservative teachings taken as universal though theologically undermined here as elsewhere homosexuality is considered an "inclination, though not itself a sin' which still 'constitutes a tendency towards behavior that is intrinsically evil, and 
therefore must be considered objectively disordered" (From the Catechism of the Catholic Church as cited in Alison, 2003, p. 93). Given this intrinsic disorder, rooted in a certain kind of Natural Law teaching that assumes not only complementarity of genders but in particular "heterogenital complementarity" as the only just manifestation of the "moral sexual act" (Salzman \& Lawler, 2008, p. 67), the Magisterium of the Church, charged with laying down the fundamental laws of the faith, offers a "more complete definition of sexual orientation" that "distinguishes between "a homosexual tendency,' which proves to be 'transitory,' and 'homosexuals who are definitely such because of some kind of innate instinct"' (p. 65). Given that any homosexual act ${ }^{11}$ is considered morally licit because it doesn't conform to heterogenital complementarity and closes "the sexual act to the gift of life" (p. 227), the Church gave itself a bit of wiggle room to accept celibate gays, even as (or particularly as) priests. This changed in Pope Benedict's (Francis' predecessor) book, Light of the World (2010) which asserted that "The Congregation for Education issued a decision...to the effect that homosexual candidates cannot become priests because their sexual orientation estranges them from the proper sense of paternity, from the intrinsic nature of priestly being." (p. 152). The move seems meant to "head off a situation where the celibacy of priests would practically end up being identified with the tendency toward homosexuality" ( $p$ 152). It might seem an odd move given Wills' collection of data across studies that found that " 20 percent of priests were homosexually oriented" and noting that " 25 percent of priests under thirty-five" at the time of an Andrew Greeley study were gay (p. 186). Further work from Thomas Fox (as cited in Wills, 2000) suggests that "'in some cases there have been reports of predominantly gay seminaries" and other research points to "seminaries that were 70 percent gay" (p. 194).

The problem, of course, isn't that priests may or may not be gay, though the climate of the seminary and the Church writ large might suggest issues of incomplete acceptance that weigh heavily on priests and which may drive them away from vocations altogether (e.g. Alison, 2001). The issue lies in an emergent sense that the imagined gay priest, tied through stereotype to a kind of unacceptable and assumed effeminacy can become a scapegoat - "the bearer of the sins of the people...banished to the wilderness" (Spong, 2007, p. 166) - both for reduced vocations and for the 
longstanding sex abuse crisis that has haunted the Church and particularly its victims. Alongside, then, the rise of what we might call fringe movements like the 'new emangelization' has come - in answer it should be said to widespread political and now legal acceptance of gay marriage in the United States - movement towards the use of morality clauses in Catholic schools ${ }^{12}$ seen as a disciplinary mechanism, in some circles, to keep gay lay teachers in the closet about their sexuality or their feelings about equality and sexuality. The point is to note that the decrease in vocations has led to a concurrent decrease in clergy teaching in Catholic schools, the largest private school system in the world ${ }^{13}$, which has meant that more fundamentalist and conservative strains in the Church have struggled to find ways to enforce uniformity of belief (and teaching) in schools. Armstrong (2015) makes the point that "whenever a fundamentalist movement is attacked," or perceives itself as under attack, "it almost invariably becomes more extreme. It shows malcontents that their fear is well grounded: the secular world really is out to destroy them" (p. 305). Rather than engaging in a new way of approaching "the moral question for a Christian ethics of sex and gender" such that we might "socialize the body...in ways which enlarge our social capacities for compassion toward others and solidarity in the common good" (Cahill, 1996, p. 164), Burke, and other conservative (males mostly, though not only) within the Church retrench, cloaked in any number of ways, but particularly in a dual defensiveness and with nods to tradition (dogma) forgetting that "tradition must not be considered only affirmatively, but also critically" (Raztzinger, as cited in Farley, 2006, p. 186).

In the face, then, of advances in secular policy in the United States and amidst the supposed reforming movement of a Pope seen as progressive in the press (though perhaps not fully by those who are paying attention to his writings; more on this in a moment), one mode of retreat can come in the targeting of vulnerable masculinities, and another in the enforcement of gender difference. A muscular Christianity can't, in other words, tolerate any more the possible effeminacy of a gay priest, nor the effeminacy of girls in the presence of men on the altar or, "part of the struggle for hegemony in the gender order is the use of culture" and here Church norms, and recourse to tradition, "for...disciplinary purposes: setting standards, claiming popular assent and discrediting those who fall short. The 
production of exemplary masculinities is thus integral to the politics of masculinity" (Connell, 1995, p. 214). Faced with evidence that the priesthood is, in some sense, dying on the vine (and perceiving this as the result of attacks from both modernity and gender equity), the lone recourse for the fundamentalist strain in Catholic circles is to lash out: to lay the blame for the sex abuse crisis at the feet of homosexual dysfunction and in the face of the insidiousness of women contravening the accepted complementarity of the social order. Muscles flexed, the priesthood has returned to the closet. In the process an opportunity for a renewed "Christian ethics of sex and gender" has been lost, as has the chance that we might "replicate the radical social challenge of early Christianity, if not necessarily its concrete moral practices" (Cahill, 1996, p. 124). Such a challenge would note that:

Openness to the other in the intimacy of embodied selves...these human possibilities need not be limited by culturally construed boundaries of gender; they can tell us something important about transcendent bodies; and they give us clues to the kinds of loves that are stronger than death. (Farley, 2006, p. 173)

A Masculinities Studies that takes feminist theology into account has the opportunity to make such arguments, particularly when eschatology emerges.

\section{Feminism and Nuclear War}

In Tornielli and Galeazzi (2015), amidst an otherwise progressive argument for socially just economic practices (the title of the book is, after all, This Economy Kills: Pope Francis on Capitalism and Social Justice), the pontiff draws some troubling connections worth encountering and challenging. $\mathrm{He}$ notes that every 'historical period has 'Herods' that 'destroy, that plot designs of death, that disfigure the face of man and woman, destroying creation." 14 In the process he condemns gender theory and likens "it to nuclear war and genetic manipulation." 15 He continues, saying, "let's think of the nuclear arms, of the possibility to annihilate in a few instants a very high number of human beings...Let's think also of genetic manipulation, of the manipulation of life, or of the gender theory, that does not recognize the 
order of creation." This abiding sense of the end-times, that a developing understanding of gender on a continuum brings about something akin to the fiery destruction of the Earth by atomic fission is mirrored in a press conference given by the pope in which he spoke of gender theory in the same vein as "ideological colonization" on par with "the Hitler youth.", These pronouncements do not sound much like the man who was, to this point, most famous in the popular media for his off-the-cuff response 'who am I to judge?' - when asked in the abstract about gay priests. As regards gender theory, however, it seems one might choose to judge away, harshly, and with not a bit of hyperbole along the way. This aligns him much more closely than most casual observers would suspect — as the narrative tends to be that his papacy is a break from if not a direct rebuttal to — with his predecessor Benedict. The pope emeritus noted in a "2012 Christmas address":

People dispute the idea that they are given a nature, given by their bodily identity, that serves as a defining element of the human being. They deny their nature and decide that it is not something previously given to them, but that they make it for themselves. According to the biblical creation account, being created by God as male and female pertains to the essence of the human creature. This duality is an essential aspect of what being human is all about, as ordained by God. This very duality as something previously given is what is now disputed.

One might be tempted to wonder just what God was doing as regards this duality in the creation of individuals who are intersex, of course. But the larger point is that in the face of something viewed as wholly secular (gender theory) the patriarchal structure of the Catholic Church (and many other churches) dismisses out of hand the relevance of such thinking to a perceived sacred sphere of belief. The work of a Masculinities Studies that takes religion seriously (for reasons other than to dismiss it out of hand as so much superstition) would be to engage very explicitly in how we might use gender theory, and particularly masculinities studies at the intersection of theology precisely to complicate such atomistic thinking.

Such work would mean, of course, addressing the hegemony of patriarchy through Connell (1995) noting that "the struggle for hegemony 
in the gender order...use[s]...culture for...disciplinary purposes" thus producing, in a religious patriarchal hegemony "exemplary masculinities" (p. 214) for the ends of politics and the maintenance of the status quo. Further, though, it would mean drawing on critiques of passive theology that "inculcates a resigned attitude toward the way things are" where there "is little motivation to change the social order" (Johnson, 2007, p. 73). This activist theology, that seeks to change the social order (not to say vaporizing it in a mushroom cloud) flags the "philosophical 'myth' of gender dualism" and seeks to actively "reorient the imagination" of and about God and religion at a "basic level" (p. 109) using the tools of religion turned in on itself. It would mean turning to a history that reads the early Christian movement for its gender equality (Wills, 2006) and taking seriously the "first 30 years of the movement" where "women were not restricted in the leadership roles they could assume" (DeConick, 2011, p. 73). That means, of course, wading through two millennia of detritus but what is queer and gender work if not anthropology; genealogy? This work would explicitly engage the notion that "what is striking is that any particular tradition's internal understanding of sexuality and gender might have developed differently had there been some variation in particular circumstances" (Farley, 2006, p. 104). Masculinities can do the work of rethinking religion and patriarchy and it can do this work without making war with faith. That takes, however, careful engagement with the seriousness of theological tools, in conversation with gender theory. My hope is that some of this work has been begun here.

\section{Concluding}

This is, in essence, a call to resacralize Masculinities Studies. A movement in that direction would require accepting the notion that "secularization should no longer be the assumed position for theorists" (Davie, as cited in Wexler, 2013, p. 5) in the social sciences for it misses the ways in which religion and theological understandings of the world have always already existed in the supposed secular. A facile sense that the secular is ever the constitutive outside to the sacred tends to be rooted in an historical analysis that sees the Enlightenment as a shift from superstition to scientism, as it were. That narrative, however, misses the fact that the "Enlightenment was 
always also religious" (p. 23) and fails to account for the difficulty of understanding "our perceptions of the world, our philosophical conception of the soul, of immortality, of life, if one does not know the religious beliefs which are their primordial forms" (Durkheim, as cited in Wexler, 2013, p. 76). To better understand the possibilities and commitments of Masculinities Studies one must grapple with the fact that "sociocultural knowledge has its basis in religious traditions, at the core of which is religious experience" (p. 82).

Resacralization, then, would mean turning to the very religious traditions that most flailingly perpetuate the kinds of hegemonic masculinist and positivist salvific narratives and engaging them on their own terms. Certainly traditionalists within a given church, and here Catholicism, will be able to lean on the dual rails of accepted dogma and more conservative theologians. But that will have always been the case anyways; the only way toward conversation, and perhaps change, is thinking through how theology gives us the chance to speak in a language that is seen as authoritative (not to say authoritarian) to the very audience we seek to challenge and redirect. In that regard, then, we leave here noting that "scripture, then, and traditional theological, doctrinal formulations are the result of reflexive, critical, human construal and have to be, therefore, as sociohiostircally conditioned as its contruers themselves" (Salzman \& Lawler, 2008, p. 13). Ultimately, the authors conclude, theology must be in dialog with human experience. I would suggest here that this dialog, and the experiences it might explain, challenge, and support, would be greatly served by being taken up in Masculinities Studies much more robustly.

\section{Notes}

${ }^{1}$ One particular example might be a recent report from the Vatican that, after three years of investigations into the Leadership Conference of Women Religious from the doctrinal watchdog within the Catholic Church, the Congregation for the Doctrine of Faith, the religious sisters represented by the LCWR have been, colloquially, let off the hook. That the investigation for dogmatic irregularities was initiated under the prior pope (especially for the nuns' lack of zeal in publicly and constantly affirming Church teachings around abortion specifically and women's issues generally) has not been lost on observers of the Church.

${ }^{2}$ Religionandgender.org

3 http://www.jmmsweb.org/ 


\section{Kevin J. Burke - Liking Theology in Masculinities Research}

${ }^{4}$ There aren't currently any Catholic versions of fight church, though Catholic schools have long promoted boxing as a charitable as well as inherently masculine pursuit, in service of the missions and Christ (e.g. http://bengalbouts.nd.edu/); Basketball, however, long a part of Catholic Youth Organizations seems a ready corollary, perhaps best instantiated in this diocesan recruiting video:

http://www.heroicpriesthood.com/?utm_source=Copy+of+Heroic+Priesthood\&utm_campaig $\mathrm{n}=$ Relaunch+of+topical+Study+programs\&utm_medium=email

${ }^{5}$ http://www.newemangelization.com/the-new-emangelization-project-2/

${ }^{6} \mathrm{http}: / /$ www.newemangelization.com/uncategorized/cardinal-raymond-leo-burke-on-the-cath olic-man-crisis-and-what-to-do-about-it/

${ }^{7}$ http://www.usccb.org/beliefs-and-teachings/how-we-teach/new-evangelization/

${ }^{8}$ http://www.catholicnews.com/data/stories/cns/1303303.htm

${ }^{9}$ http://www.bbc.com/news/world-21443313

${ }^{10} \mathrm{http}: / /$ ncronline.org/news/faith-parish/had-it-catholics

${ }^{11}$ Given that the teachings of the Church create something of a taxonomy here, one can quickly fritter the distinction to absurdity merely by suggesting that if one is ontologically 'gay' as the Church suggests, then any act committed (sexual or not) is thus homosexual and morally licit making the very existence of a gay person verboten in Church teaching.

12 http://www.wcpo.com/news/local-news/hamilton-county/cincinnati/archdiocese-of-cincinn ati-catholic-teacher-contract-edit-to-clarify

13 http://www.ncea.org/data-information/catholic-school-data

${ }^{14} \mathrm{http}$ //ncronline.org/news/vatican/francis-strongly-criticizes-gender-theory-comparing-nucl ear-arms

15 https://www.commonwealmagazine.org/blog/gender-theory-nuclear-war-and-nazis-0

16 http://www.ncregister.com/daily-news/pope-francis-warns-west-over-ideological-colonizati on

${ }^{17}$ https://www.commonwealmagazine.org/blog/gender-theory-nuclear-war-and-nazis-0

\section{References}

Alison, J. (2001). Faith beyond resentment: Fragments Catholic and gay. New York: Crossroad Publishing Group.

Alison, J. (2003). On being liked. New York: Herder \& Herder.

Armstrong, K. (2015). Fields of blood: Religion and the history of violence. New York: Alfred A. Knopf.

Burke, K. J. (2011). Masculinity and other hopeless causes at an all-boys catholic school. New York: Peter Lang.

Burke, K. J. (2012). A space apart: Kairos and masculine possibility in retreats of adolescents. Journal of Men, Masculinities and 
Spirituality, 6(2), 77-93. Retrieved from http://www.jmmsweb.org/ issues $/$ volume6/number2/pp77-93?page $=2$

Butler, J. (2004). Undoing gender. New York: Routledge.

Butler, J. (2008). Gender trouble: Feminism and the subversion of identity:

Routledge.

Butler, J. (2010). Frames of war: When is life grievable? New York: Verso.

Cahill, L. S. (1996). Sex, gender \& Christian ethics. Cambridge:

Cambridge University Press.

Connell, R. W. (1982). Making the difference: School, families and social division. Sydney: George Allen and Unwin.

Connell, R. W. (1995). Masculinities. Oxford: Blackwell Publishers.

Connell, R. W. (2002). Gender. Malden, MA: Polity Press.

Daly, M. (1973). Beyond god the father: Toward a philosophy of women's liberation. Boston: Beacon Press.

DeConick, A. D. (2011). Holy misogyny: Why the sex and gender conflicts in the early church still matter. New York: Continuum.

Farley, M. A. (2006). A framework for Christian sexual ethics. New York:

Continuum.

Foucault, M. (1988). The care of the self: The history of sexuality (R.

Hurley, Trans. Vol. 3). New York: Vintage Books.

Gelfer, J. (2013). Meat and masculinity in men's ministries. Journal of Men's Studies, 21(1), 78-91. doi: 10.3149/jms.2101.78

Halberstam, J. (1998). Female masculinity. Durham, NC: Duke University Press.

Hall, S. (1992). Cultural studies and its theoretical legacies. In L.

Grossberg, C. Nelson, \& P. Treichler (Eds.), Cultural Studies (pp. 277-294). New York: Routledge.

Harris, I. M. (1995). Messages men hear: Constructing masculinities.

London: Taylor \& Francis.

Johnson, E. A. (2011). Quest for the living God: mapping frontiers in the theology of God. New York: Continuum.

Kimmel, M. S. (2011). Manhood in America: A cultural history (3 ed.): Oxford University Press, USA.

Korte, A.-M. (2011). Openings: A genealogical introduction to religion and gender. Religion \& Gender, 1(1), 1-17. Retrieved from http://www.religionandgender.org/index.php/rg/article/view/31 
Krondorfer, B. (2010). Male confessions: Intimate revelations and the religious imagination. Stanford: Stanford University Press.

Longhurst, R. (2001). Trim, taut, terrific, and pregnant. In D. Bell, J. Binnie, R. Holliday, R. Longhurst, \& R. Peace (Eds.), Pleasure zones: Bodies, cities, spaces (pp. 1-28). Syracuse: Syracuse University Press.

Mac an Ghaill, M. (1994). The making of men: Masculinities, sexualities and schooling. Buckingham: Open University Press.

Madigan, P. (2011). Women and fundamentalism in Islam and Catholicism: Negotiating modernity in a globalized world. Bern: Peter Lang. McCormack, M. (2012). The declining significance of homophobia: How teenage boys are redefining masculinity and heterosexuality. New York: Oxford University Press.

Nord, W., \& Haynes, C. C. (1998). Taking religion seriously across the curriculum. Alexandria, VA: ASCD.

Pascoe, C. J. (2007). Dude, you're a fag: Masculinity and sexuality in high school. Berkeley: University of California Press.

Pope Benedict, XVI. (2010). Light of the World: The Pope, the Church, and the Signs of the Times. A Conversation with Peter Seewald. San Francisco: Ignatius Press.

Salzman, T. A., \& Lawler, M. G. (2008). The sexual person: Toward a renewed catholic anthropology. Washington, DC: Georgetown University Press.

Thorne, B. (1993). Gender play: Girls and boys in school. New Brunswick: Rutgers University Press.

Tornielli, A., \& Galeazzi, G. (2015). This economy kills: Pope Francis on capitalism and social justice. Collegeville, MN: The Liturgical Press. Wexler, P. (2013). Mystical sociology: Toward a cosmic social theory. New York: Peter Lang.

Wills, G. (2000). Papal sin: Structures of deceit. New York: Image Books. Wills, G. (2006). What Paul meant. New York: Viking Adult. 


$$
\text { MCS - Masculinities and Social Change, 4(2) } 163
$$

Kevin Burke is an Assistant Professor of English Education at the University of Georgia, United States.

Contact Address: Direct correspondence to Kevin Burke, Aderhold Hall, University of Georgia, Athens, GA. 30605, email:

burkekq@uga.edu 